St ud i P hiloso phic a

Wr a t i s l a vi e n s i a

vol. XVI, fasc. 3 (2021)

https://doi.org/10.19195/1895-8001.16.3.5

MAREK WOSZCZEK

ORCID: 0000-0003-3833-5001

Uniwersytet im. Adama Mickiewicza w Poznaniu

\title{
Bez geniuszów, bez cudów - w kolektywie. Głos w dyskusji nad nową książką Wojciecha Sadego
}

\section{Neither geniuses nor miracles, just collective. Some remarks a propos a new book by Wojciech Sady}

\begin{abstract}
The paper indicates how an original Fleckian core of Wojciech Sady's methodology significantly weakens some popular presentations of the history of empirical sciences (especially the so-called scientific revolutions), which are founded on a myth of a 'lonely genius' and 'miraculous ideas'. Sady rightly emphasizes the collective-cognitive character of processes shaping the theoretical breakthroughs in physics, however he unnecessarily contends that there is some determinism behind them. In order to understand their dynamics, one needs the fine-grained historical-sociological analyses concerning the factors which regulate the work of the research collectives (also the early modern ones), but the widespread individualistic myths make that task much harder, even in a field of critical philosophy of science. It is suggested that the Fleckian perspective is also quite crucial in explaining the seemingly paradoxical waves of antiscientific sentiments which are clearly visible in the hypertechnological societies.
\end{abstract}

Keywords: Ludwik Fleck, research collectives, scientific revolution, quantum theory, theoretical convergence

Książka Wojciecha Sadego Struktura rewolucji relatywistycznej i kwantowej w fizyce jest odważna, ponieważ mierzy się z materią zbadaną dokładnie przez historyków fizyki oraz poddaną w drugiej połowie XX wieku niesłychanie rozbudo- 
wanym, goracym dyskusjom w filozofii nauki. Problemy rewolucji naukowej i odkrycia są w tej ostatniej zagadnieniami kanonicznymi, więc trzeba nie lada odwagi, by zaproponować ujęcie własne, niezależne od opcji dominujących w przepastnej literaturze ostatnich dziewięćdziesięciu lat. Fakt, że przewodnikiem Sadego w badaniu tego, co działo się w fizyce na przełomie XIX i XX wieku, jest explicite Ludwik Fleck z jego unikalnymi koncepcjami stylu i kolektywu myślowego, od początku sygnalizuje specyficznie poznawczo-socjologiczną perspektywę, która do lat osiemdziesiątych była praktycznie nieznana lub wprost ignorowana $\mathrm{w}$ literaturze anglojęzycznej ${ }^{1}$. Jak to się mogło stać z Fleckiem, to osobna historia ${ }^{2}$; sam Sady napisał teraz, używając fleckowskich narzędzi, świeżą rekonstrukcję fragmentu historii fizyki, którą można było w zasadzie rozwijać już kilkadziesiąt lat temu. Jest to więc praca ,klasyczna” w sensie osadzenia, stylu, perspektywy i ambicji, ale — co zaskakujące — daje do myślenia w takim samym stopniu, jak prace owych klasyków, z którymi ostro, i słusznie, polemizuje. Chciałbym odnieść się krótko do kilku aspektów tej polemiki, ale także podzielić się szerszą refleksją czytelnika myślącego o nauce w czasie zaskakujaccego kryzysu zaufania do niej.

Od początku lat osiemdziesiątych XX wieku, zanim ponownie dostrzeżono Flecka, dokonała się w samej filozofii za sprawą „zwrotu ku laboratorium” cicha rewolucja — bynajmniej nie tylko korekta - antyteoretycystyczna w badaniu procesu wytwarzania wiedzy naukowej, której ogromnym zyskiem było szybkie dojrzewanie socjologii i antropologii nauki ${ }^{3}$. Drugi, powiązany nurt tej rewolucji dotyczył podejścia kognitywno-konstruktywistycznego ${ }^{4}$. Sady niestety nie odnosi się do niej ani nie wzmiankuje prac z tego zakresu, sac one u niego zupełnie przemilczane, ale niejako okrężną drogą — za sprawą Flecka, którego podziwia — afirmuje i broni fundamentalnego przesunięcia akcentów, które się dokonało: nacisku na społeczno-kolektywny charakter wytwarzania wiedzy naukowej i związane z tym zupełnie unikalne procesy zachodzace w takich podtrzymywanych i stabilizowanych kolektywach myślenia, eksperymentowania i interakcji. Z dzisiejszej perspektywy wydaje się

${ }^{1}$ Sady jest autorem dobrego hasła Ludwik Fleck w Stanford Encyclopedia of Philosophy; https:// plato.stanford.edu/entries/fleck.

2 Wynikało to między innymi z zawstydzającego anglocentryzmu późniejszej filozofii nauki (znacząca część autorów po prostu nawet nie czytała i nie czyta po niemiecku, tak jak i po francusku czy włosku), ignorowania socjologii i psychologii (zwł. nieznajomości niemieckiej tradycji socjologicznej i psychologicznej lat dwudziestych i trzydziestych, stanowiącej zaplecze myśli Flecka) oraz akademickiej dominacji Poppera, Kuhna i Lakatosa, przy czym ten drugi przeobraził, zupełnie zmieniając jego teoretyczną funkcję, Denkstil Flecka w swoją koncepcję paradygmatu. Na temat tła historycznego i teoretycznych napięć z tym związanych zob. np. B.E. Babich, From Fleck's Denkstil to Kuhn's paradigm: Conceptual schemes and incommensurability, „International Studies in the Philosophy of Science” 17 [1] (2003), s. 75-92. Gorzki komentarz Sadego w kontekście ewolucji jego własnych badań: W. Sady, Struktura rewolucji relatywistycznej i kwantowej w fizyce, Kraków 2020, s. 16.

${ }^{3}$ Fundamentalne prace od końca lat siedemdziesiątych pisali Bruno Latour, Steve Woolgar, Karin Knorr Cetina, Steven Shapin, Simon Schaffer, Ian Hacking, Andrew Pickering, Michael Lynch, Peter Galison, Sharon Traweek i wiele innych.

4 Impet nadała praca Ronalda N. Giere'a Explaining Science: A Cognitive Approach z $1988 \mathrm{r}$. oraz seminarium na University of Minnesota w październiku 1989 r. (materiały z niej zostały wydane w Cognitive Models of Science, R. Giere, H. Feigl (eds.), Minneapolis 1992). Giere, podobnie jak wówczas wielu innych, przedstawiał siebie jako umiarkowanego konstruktywistę. 
to może czasem trywialne, ale podtrzymywany paradygmat teoretycystyczno-analityczny w filozofii nauki przez całe dekady XX wieku był niezdolny, czasem wręcz patologicznie, do ich dostrzeżenia i zrozumienia, nie mówiąc o jakimkolwiek ich badaniu. Książka Sadego plasuje się jednak gdzieś w połowie drogi (Autor podkreśla okazjonalnie rolę czynników kulturowych, ekonomicznych czy politycznych) i w tym sensie jest, jak stwierdziłem, jeszcze „klasyczna” w sensie perspektywy i stylu, ale w centrum, i to jest jej zaleta, stawia historyczno-społeczno-kognitywny charakter tego, co zwyczajowo określa się „rewolucją naukową”. Jest to więc solidny fleckowski rdzeń metodologiczny całej książki.

Obraz, jaki stąd wynika - i antypopperowski, i antykuhnowski - może być zapewne dla wielu czytelników zaskakujący albo wręcz obcy: w „rewolucjach” jest o wiele mniej rewolucji niż się wydaje, zwłaszcza filozofom, za to mnóstwo mrówczej, powolnej, zupełnie przyziemnej pracy w kolektywach badawczych, psychologicznych uwarunkowań pracujaccych uczonych ${ }^{5}$, a także mrowie błędów (widocznych post hoc i zawsze w konkretnym kontekście, nie błędów simpliciter), ślepych zaułków, pomylonych, bezpłodnych modeli, leżących odłogiem kłopotliwych wyników doświadczalnych, wyuczonych szablonów, bardzo konserwatywnych prowizoriów i stosowanych odruchowo heurystyk. Wszystko to dlatego, że nikt nie pracuje jako czysty intelekt i właścicielka języka, nie myśli samotnie i nie eksperymentuje samotnie, mimo, że czasem taka mitologia była podtrzymywana przez popularyzatorów nauki. „Rewolucja” w fizyce to raczej pojęcie-wytrych, które kluczowe aspekty, widoczne tylko „z bliska”, ukrywa, tak jak filozofowie analityczni programowo „ukrywali” socjologię, historię, kulturę, ekonomię. Sady jest wrogiem takiego ukrywania, a przede wszystkim „wymyślania historii nauki wstecz”, nawet w celach pedagogicznych — i ma w tym rację, choć nie jest to przecież nowość.

Jednocześnie, w zgodzie ze stanowiskiem Flecka, dystans do pojęcia rewolucji wcale nie oznacza zgody na tezę o historycznej kumulatywności, prostej liniowości postępu naukowego, nie zachodzi tu konieczność teoretycznego wyboru albo-albo. Powoduje to, że wielu czytelników książki być może uświadomi sobie po raz pierwszy, jak niewiarygodnie trudne i najeżone pułapkami jest pisanie historii nauki, wbrew zdumiewającej pewności siebie i dezynwolturze wielu jej popularyzatorów. Jest to jeden z przykładów sytuacji, gdy filozofia może pomóc także zawodowym historykom przez wzbudzenie, po fleckowsku, naprawdę zasadniczych wątpliwości odnośnie do samego sposobu pisania oraz naiwności metodologicznej, słabości sto-

${ }^{5}$ Sady starannie unika uprawiania naiwnej psychologii „genialności”. Sugeruje tylko, że pewne cechy, które w innych interakcjach mogą wręcz utrudniać społeczne funkcjonowanie, w bardzo specyficznej pracy w kolektywach naukowych mogą, choć nie muszą, po prostu sprzyjać skłonności do myślowego eksperymentowania z niestandardowymi rozwiązaniami czy stymulującemu przez lata pracę uporowi badawczemu (por. uwagi na temat Einsteina - W. Sady, Struktura rewolucji relatywistycznej i kwantowej $w$ fizyce, s. 117; przykład odwrotny bardzo zachowawczego Plancka - ibidem, s. 142). Takie chłodne spojrzenie nieco odziera postaci historyczne z romantycznego nimbu ,genialnych umysłów", który, co ciekawe, jest często podtrzymywany z aprobatą mimo jednoczesnej deklarowanej odrazy do psychologizmu w filozofii nauki. Sam Fleck zauważył w swoim fascynującym eseju Patrzeć, widzieć, wiedzieć z 1947 r., że jest ono niemile widziane również przez samych uczonych, chętnie postrzegających siebie jako indywidualistów, unikalne umysły czy samotnych bojowników, co jest jednak jednostkową iluzją.

${ }^{6}$ Por. przykłady w W. Sady, Struktura rewolucji relatywistycznej i kwantowej w fizyce, s. 11. 
sowanej optyki, prowadzącej do tworzenia mitów. Jednym z tych wygodnych przy pisaniu historii mitów jest staroświecki „popperowski” indywidualizm (antykolektywizm) w ujmowaniu rozwoju nauki, w tym szczególna rola przypisywana zdolnościom jednostkowych umysłów, na przykład intuicyjnemu ,wglądowi”, intelektualnej odwadze, wyjątkowej inteligencji czy anarchicznej „twórczej wolności”. Taka optyka, o czym niezmordowanie przekonywał Fleck, wytwarza zwykle karykaturę nauki, która była i jest przedsięwzięciem stricte kolektywnym, wspólnotowym, we wszystkich jej aspektach, nawet psychologicznych. Sady oczywiście ma rację w odniesieniu do tych ostatnich: do uprawiania nauki w kolektywie jest się tre now any m - społecznie, kognitywnie, językowo, wręcz behawioralnie, i dlatego procedury naukowe sa tak systematyczne i efektywne. Chodzi nie tylko o nowoczesna pracę laboratoryjną jako prototyp, ale o każdą mikroaktywność naukową (również nieempiryczną), którą rządzi metodologia na długo już nawet przed etapem zbierania danych i próbek czy konstruowaniem dowodu ${ }^{7}$.

Jedną z ważniejszych zalet takiego podejścia w kontekście fizyki jest koncepcja „rewolucji na papierze, nie w umyśle”, którą Sady przekonująco wspiera przede wszystkim kazusem narodzin teorii relatywistycznej z klasycznej elektrodynamiki, będącym szczególnie dogodnym przykładem takiego rozwoju wypadków. Wypada jednak od razu zauważyć, że w przypadku teorii kwantów zatrzymuje się w zasadzie na teorii Bohra z 1913 roku, właściwe zaś narodziny zupełnie nowej mechaniki z lat 1925-1926 — teorii macierzowej Heisenberga i niezależnej teorii Diraca — nie są w ogóle analizowane, lecz podane na końcu w telegraficznym skrócie (s. 206-207 książki), nie mówiąc o kwantowej teorii pola, która wzmiankowana jest jednym tylko zdaniem. Jest tak chyba nieprzypadkowo: algebraiczne teorie Heisenberga-Bor-

7 Prowokacyjnym, współczesnym kontrprzykładem z zakresu nauk formalnych, który sugerowałbym jako ciekawe wyzwanie dla Sadego, jest kazus dowodu słynnej hipotezy ABC (Oesterlégo-Massera) z teorii liczb, który w połowie 2012 r. przedstawił japoński matematyk Shin’ichi Mochizuki z Uniwersytetu Kioto. Sześćsetstronicowy dowód został sformułowany w całkowicie nowym formalizmie i przy użyciu nowych pojęć oraz technik, nieznanych istniejącej matematyce, co sprawiło, że był w całości niezrozumiały (począwszy od pierwszych kroków) dla kogokolwiek we wspólnocie matematyków, włączając czołowych na świecie teoretyków liczb (zob. np. D. Castelvecchi, The biggest mystery in mathematics: Shinichi Mochizuki and the impenetrable proof, „Nature” 526 (2015), s. 178-181). W istocie dowód Mochizukiego to nie tylko alternatywny formalizm (który nazywa ,geometrią interuniwersalną"), lecz także rodzaj alternatywnej matematyki, zbudowanej od podstaw przez jednego człowieka, stąd większość teoretyków nadal uznaje go (tak jak i pisemne wyjaśnienia Mochizukiego) za niedający się prześledzić ani zrozumieć, nawet we fragmentach, pomimo trwających od ośmiu lat intensywnych seminariów i konferencji, a także próby wstępnego streszczenia-parafrazy przez Go Yamashitę z 2017 r. W ubiegłym roku jednak ogłoszono, że ostateczna wersja dowodu zostanie opublikowana w wydaniu specjalnym japońskich Publications of the Research Institute for Mathematical Sciences (D. Castelvecchi, Mathematical proof that rocked number theory will be published, „Nature” 580 (2020), s. 177), co jest w historii współczesnej matematyki sytuacją bez precedensu. W tym sensie różni się ona zasadniczo od przypadku rękopiśmiennych prac Alexandra Grothendiecka z lat siedemdziesiątych i osiemdziesiątych, w których wszystkie nowe pojęcia i techniki (np. geometrii anabelowej czy dessins d'enfants, w czym specjalizuje się też Mochizuki) można było odnieść do już istniejącej geometrii i topologii algebraicznej. Jest to przykład tego, jak może zachodzić tworzenie całych formalizmów i teorii w o wiele radykalniejszym (,rewolucyjnym”) sensie niż ten, do którego obecnie przywykliśmy w matematyce i logice (abstrahując od historycznych przykładów tworzenia rachunku różniczkowego i całkowego, Ausdehnungslehre Hermanna Grassmanna czy teorii kategorii). 
na-Jordana czy Diraca, nie mówiąc o późniejszym sformułowaniu von Neumanna, są innowacyjnymi tworami teoretycznymi, które w dużym stopniu nie mają wiele wspólnego ze strukturą mechaniki klasycznej, a niektóre dowody z tego wczesnego okresu nie są nawet ścisłymi dowodami matematycznymi. W sensie pomysłów teoretycznych na całościową mechanikę, poza ogólnymi, nowymi heurystykami (kwantyzacji, hipotezą adiabatyczną Ehrenfesta z 1913 roku i zasadą korespondencji Bohra z 1920 roku) były więc trochę out of the blue, choć może nie „gestami desperacji”" jak w dawnym przypadku Plancka, a ich niebywały sukces i fundamentalny charakter okazał się jednak dość zaskakujący.

Osobiście uważam jednak, że nawet te przypadki niekoniecznie są problemem dla ujęcia proponowanego przez Sadego, o ile dokładnie przyjrzeć się dynamice fermentu teoretycznego, artykułów i dyskusji od 1919 roku (czego Sady jednak nie robi). Nawet ta niebywała innowacyjność matematyczna młodych teoretyków (na przykład teoria wirtualnych oscylatorów i wirtualnego pola promieniowania Slatera-Bohra-Kramersa z 1924 roku $^{8}$ ) rozgrywała się jak najbardziej w kolektywie, a to, że Heisenberg i Dirac niezależnie wpadli na swoje sformułowania algebraiczne, z pewnością nie jest cudem, lecz efektem tej dynamiki, wyłaniających się kierunków myślenia i zgadywania wspartego przyjętymi heurystykami. Być może już tutaj Sademu udałoby się to pokazać, jednak historia ta jest o wiele bardziej powikłana i „gęsta" niż w przypadku Einsteina - a jeszcze bardziej z kwantową teorią pola, zwłaszcza po wojnie. Dochodzimy wszakże do drugiej zalety książki: pokazania, że pozorne „cudy” zbieżności między teoretykami i synchronizacji pomysłów wcale nimi nie są. Także w tym przypadku historycy fizyki lubiac czasem pisać o „cudownych ideach”, „cudownych koincydencjach” czy ,iskrach geniuszu”, ale drobiazgowa analiza z dużą rozdzielczością czasową z reguły nie pozostawia zbyt wielu złudzeń. Obraz jest mniej romantyczny, ale za to ciekawszy z perspektywy socjologii nauki, ponieważ pokazuje, jak realnie przebiega praca kolektywu badawczego w spr zyjający ch, wspierających warunkach, do których należą: odpowiednie zagęszczenie interakcji (w tym osobistych między uczonymi), sprawność komunikacji wyników i duża swoboda akademickiej transmisji wiedzy (w tym zwłaszcza dotyczącej otwartych problemów, niejasności, kontrowersji oraz nowych metod i podejść $)^{9}$, solidna organizacja instytucjo-

\footnotetext{
8 Idea ta, w poprawionej i zmodyfikowanej postaci, leży w zasadzie u podstaw całej późniejszej kwantowej teorii pola.

9 Jest to właściwie kluczowa kwestia z perspektywy historii nauki wczesnonowożytnej, która od dawna jest już dokładnie badana. Z nowszych prac dotyczących krytycznej roli wczesnych akademii naukowych i ich fascynującej socjologii, także w kontekście procesów politycznej demokratyzacji i radykalnej redefinicji nobilitas, zob. zwłaszcza: Europäische Sozietätsbewegung und demokratische Tradition. Die europäischen Akademien der Frühen Neuzeit zwischen Frührenaissance und Spätaufklärung, t. 1-2, K. Garber, H. Wismann, W. Siebers (hrsg.), Tübingen 1996; J. Henry, The Scientific Revolution and the Origins of Modern Science, Basingstoke 2002; J. Robertson, The Case for the Enlightenment: Scotland and Naples 1680-1760, Cambridge 2005, s. 94-146; S. Testa, Le Accademie senesi e il network intellettuale della prima età moderna in Italia (1525-1700). Un progetto online, „Bullettino senese di Storia Patria" 117, 2010, s. 613-637; The Italian Academies, 1525-1700: Networks of Culture, Innovation and Dissent, J.E. Everson, D.V. Reidy, L. Sampson (eds.), Cambridge-New York 2016; The Institutionalization of Science in Early Modern Europe, M. Feingold, G. Giannini (eds.), Leiden-Boston 2020. Dotyczy to również późnoantycznych i średniowiecznych sieci oraz centrów
} 
nalna i dostępność danych ${ }^{10}$, stabilne (państwowe) finansowanie (nawet przy pewnej niestabilności politycznej) czy otwarcie na nowe pokolenia studentów instytucjonalnie ćwiczonych do konfrontacji z otwartymi problemami. Te powiązane czynniki maja większe znaczenie z perspektywy socjologii tak zwanej rewolucji naukowej niż rzekomo wyjątkowe cechy przedsiębiorczych badaczy-indywidualistów, którzy mieliby „popychać naukę do przodu” dzięki swojej „,boskiej iskrze” nieustępliwego geniuszu ${ }^{11}$.

Pułapką, w którą wpadł jednak Sady, jest zbyt łatwe przejście od ciekawej koncepcji „rewolucji na papierze” i eliminującej rzekome cudy „logiki zgadywania”, działajaccej wewnątrz pola badawczego i opartej na dostępnych heurystykach i danych eksperymentalnych, do niezwykle mocnej tezy o determinizmie rozwoju nauki, która nagle pojawia się w rozdziale 8.3 . W moim przekonaniu jest ona niewiarygodna i pośpieszna — niepotrzebnie ekstrapoluje wyniki uzyskane w książce, które są przecież interesujące per se nawet w tym wąskim zakresie. Krytyka tej tezy wymagałaby osobnego wywodu, ale zauważę jedynie, że wspomniane przejście jest błędem, ponieważ opisana przez Sadego dynamika rozwoju fizyki na przełomie XIX i XX wieku działała (i działa nadal) tylko w sytuacji spełniającej kilka bard zo w yjątkow ych warunków poza tymi ogólnymi, które wskazałem wcześniej. W kontekście „rewolucji” w fizyce najbardziej oczywista jest rola (1) ustabilizowanej (względnej) jednorodności teorii i praktyki w obrębie dyscypliny ${ }^{12}$ oraz (2) matematyzacji badań. Nic dziwnego, że w tych warunkach rewolucja może dokonać

transmisji wiedzy, takich jak Aleksandria, Konstantynopol, Edessa, Bagdad, Fez, Kordoba czy Toledo, jednak tu materiał historyczny jest o wiele uboższy.

$10 \mathrm{Na}$ temat fundamentalnego znaczenia wczesnowożytnego rozwoju archiwizacji w kontekście politycznym zob. zwł. studium R.C. Heada Making Archives in Early Modern Europe: Proof, Information, and Political Record-Keeping, 1400-1700, Cambridge 2019. W wypadku nauki, poza tradycyjnymi bibliotekami i późniejszą siecią samych czasopism/biuletynów/materiałów konferencyjnych, współcześnie są to oczywiście wirtualne biblioteki danych czy wyszukiwarki i gigantyczne, otwarte repozytoria takie jak arXiv, bioRxiv, chemRxiv, NLM, PubMed, GenBank, MathSciNet, GEOBASE, IRSA, NASA/ IPAC czy SDSS. W tym sensie nauka nie istnieje bez organizacji danych i systematycznej archiwizacji, dzięki której kolektywy badawcze mogą się organizować — ich długa, przednowożytna historia sięga takich instytucji jak Muzejon w starożytnej Aleksandrii czy Dom Mądrości w średniowiecznym Bagdadzie. Bez tego historia nauki jest chaotyczną historią krążenia tekstów, ludzi czy instrumentów.

11 Ta postromantyczna mitologia uczonego jako wybitnej indywidualności, efektywnie rozwijającej dla wybranych swoje oryginalne seminarium jako przedsięwzięcie, a także stowarzyszona z nią biurokratyczna idea „uniwersytetu badawczego” są łącznie wytworem specyficznej konfiguracji społeczno-historycznej w świecie protestanckim XVIII/XIX wieku i przekształceń w procesie produkcji wiedzy, poddanej urzędowemu ocenianiu i ekonomicznej presji rynku — zob. zwł. W. Clark, Academic Charisma and the Origins of the Research University, Chicago-London 2006. W tym sensie także współczesny kształt akademickiej produkcji jest końcowym efektem tego długiego procesu. Na autoiluzję uczonych z tezy Flecka z 1947 r. (p. przyp. 5) należy więc spojrzeć także ściśle historycznie jako przewidywalną konsekwencję tej specyficznej instytucjonalnej socjalizacji, behawioralnego treningu. Szkoda, że zabrakło tego historycznego aspektu w rozdz. 8.8. książki Sadego (na s. 220).

12 Oczywiście jest ona względna zawsze — w przypadkach badanych w książce zachodziły dyskutowane przez Sadego niespójności, niejasne związki i różnice w formalizmach między mechaniką klasyczną, teorią elektromagnetyzmu i termodynamiką. Współcześnie największe niespójności w podstawach fizyki dotyczą relacji teorii klasycznych (w tym grawitacji) i kwantowych. W niektórych przypadkach prowokuje to nawet konstruowanie od podstaw zupełnie nowych formalizmów, zasadniczo odmiennych od istniejących, z nadzieją na unifikację. 
się, dosłownie, „na papierze” czy „przy tablicy”, skoro jej wszyscy aktorzy pracują, operując głównie na równaniach (i słuchając nietrywialnych informacji przekazywanych z laboratoriów oraz pomysłów rzucanych w prywatnych rozmowach i podczas seminariów $\left.{ }^{13}\right)$.

W tej sytuacji mogą uruchamiać się zbiorowo procesy wnioskowania, postulowania i zgadywania, które opisał Sady, a które proponowałbym nazywać procesami konwergencyjnymi. Efektem ich działania są właśnie naiwnie spostrzegane potem „cudowne koincydencje” pomysłów/rozwiązań czy „błyski geniuszu”, które byłyby niemożliwe bez permanentnej pracy tego ukrytego zaplecza i dostatecznie rozbudowanego kolektywu ${ }^{14}$. Oczywiście w dyscyplinach, w których warunki te, a zwłaszcza matematyzacja, nie działaja, procesy konwergencyjne ujawniają się i znacznie słabiej, i wolniej albo są wręcz trwale i naturalnie zdominowane przez nieusuwalne procesy dy wergencyjne, jak w całej humanistyce, ale też i w naukach społecznych, z ogromnym pluralizmem podejść i teorii, często nieprzystawalnych. Trudno mi zrozumieć, w jaki sposób konkluzje Sadego, nie mówiąc o tezie o determinizmie, mogłyby odnosić się automatycznie do tych nauk i całej nauki jako takiej (o ile używać liczby pojedynczej). Innymi słowy, zasięg tych pierwszych, wbrew sugestiom autora, jest dość ograniczony, choć nie osłabia to ich wartości odnośnie do wskazanego zakresu książki (rewolucje w fizyce).

Na koniec krótka tylko refleksja dotyczacca znaczenia perspektywy fleckowskiej w bardzo szerokim kontekście społecznym - perspektywy, która u Sadego się nie pojawia, ale która wydaje mi się szczególnie ważna. Tworzenie antykolektywistycznych karykatur nauk empirycznych było i jest uwarunkowane od XIX wieku wspomnianymi długofalowymi czynnikami ekonomicznymi (kapitalistyczne przekształcenia uniwersytetów i prezentacji badań) i politycznymi, ale ma obecnie ogromne znaczenie dla zrozumienia kryzysów zaufania do nauki, jego łatwego, sponsorowanego podkopywania przez polityków, „handlarzy wątpliwościami”15 i organizacje

13 Kluczowa rola tych czynników w kształtowaniu się przez trzy dekady mechaniki kwantowej jest dobrze znana i opisana (robi to tylko częściowo, odnośnie do okresu przed rokiem 1913, sam Sady), np. rola monachijskiego ośrodka stworzonego przez Arnolda Sommerfelda, ośrodka getyńskiego czy Bohrowskiego Instytutu Fizyki Teoretycznej w Kopenhadze, a także niezwykle gęstej historii powiązań, intensywnych kontaktów i seminariów w drugiej i trzeciej dekadzie XX w. Współcześnie całe awangardowe instytucje naukowe projektowane i zakładane są świadomie w taki sposób, by nie tylko umożliwiać, ale wręcz prowokować takie intensywne interakcje naukowe na wszelkie możliwe sposoby. Sztandarowym przykładem jest Perimeter Institute for Theoretical Physics założony w Waterloo, w Kanadzie w 1999 roku; to samo dotyczy większości interdyscyplinarnych centrów badawczych przy wydziałach fizyki na największych uniwersytetach zachodnich i azjatyckich. Organizowane są nawet w ramach grantów międzynarodowe luźne sieci i konsorcja badawcze z zakresu podstaw fizyki, także z udziałem filozofów, takie jak ostatnio QUISS (The Quantum Information Structure of Spacetime, www.quiss.fr), które mają tę wspólną pracę stymulować w określonych kierunkach. Złożoność kolektywów badawczych i gęstość interakcji w dyscyplinach fizycznych wzrosła po stu latach w sposób niesłychany.

14 Sady trafnie pisze po fleckowsku: „Sytuacja dojrzewa w wyniku prac prowadzonych przez wspólnotę, a nie w umysłach jednostek" (Struktura rewolucji relatywistycznej $i$ kwantowej $w$ fizyce, s. 141).

15 Zob. zwł. głośne książki N. Oreskes, E.M. Conway, Merchants of Doubt: How a Handful of Scientists Obscured the Truth on Issues from Tobacco Smoke to Global Warming, London 2010; oraz C. Mooney, The Republican War on Science, New York 2005. 
religijne, regularnych fal obskurantyzmu i antynaukowych teorii spiskowych w hipertechnologicznych społeczeństwach, ale i podtrzymywanego przez cały XX wiek antyoświeceniowego resentymentu samej filozofii. Nauka fałszywie spostrzegana jako mrowie spierających się indywidualistów-atomów i otwartych „opinii”, łatanina perspektyw (,to tylko teoria”) i dzieło wolnych umysłów, z których każdy może okazać się ,geniuszem”, więc powinien być wysłuchany i oceniony jak unikatowy towar na rynku, nie tylko drastycznie zniekształca obraz pracy kolektywów badawczych, ale otwiera drogę do jej permanenentej destabilizacji jako ludzkiego wspólnego, zbiorowego przedsięwzięcia i wspólnego dobra. Od dawna nie było to tak widoczne jak obecnie, w czasie pandemii COVID-19 i autentycznego triumfu biotechnologii (technologia mRNA nowej generacji i błyskawiczna produkcja masowa) przy jednoczesnym nasileniu działalności ruchów antyszczepionkowych i teorii spiskowych na ogromną skalę.

Warto to podkreślać częściej: budowanie karykaturalnego obrazu nauk empirycznych nie jest problemem tylko teoretycznym, ale jest przede wszystkim antyspołeczne, ma poważne konsekwencje dla sposobu, w jaki społeczeństwa (naukę finansujace) percypują jej działanie, wyniki i efektywność. Pozwala to wyjaśnić pozorny tylko paradoks: w świecie, w którym najnowsze, zaawansowane technologie są obecne praktycznie w życiu codziennym lub życie ratują, ludzie nauki się boją lub wierzą szarlatanom i „demaskatorom spisku”, za co płacą, również zbiorowo, wysoką cenę. Figura samotnego „naukowego demaskatora” jest po prostu jedynie karykaturalnym wcieleniem, przedłużeniem romantycznej figury ,geniusza” i „niezależnego eksperta" na rynku, i tak społecznie funkcjonuje. Dość łatwo więc po fleckowsku zrozumieć, dlaczego ludzie nie ufają renomowanym, międzynarodowym instytucjom naukowym czy ignorują oficjalne stanowiska prestiżowych stowarzyszeń naukowych, bardzo chętnie zaś słuchają „wyrażających wątpliwości” polityków, samozwańczych ekspertów z YouTube lub kaznodziejów z organizacji religijnych. Filozofia nauki ma znaczenie społeczne.

\section{Bibliografia}

Babich B.E., From Fleck's Denkstil to Kuhn's paradigm: Conceptual schemes and incommensurability, „International Studies in the Philosophy of Science” 17 (2003), s. $75-92$.

Castelvecchi D., The biggest mystery in mathematics: Shinichi Mochizuki and the impenetrable proof, „Nature” 526 (2015), s. 178-181.

Castelvecchi D., Mathematical proof that rocked number theory will be published, „Nature" 580 (2020), s. 177.

Clark W., Academic Charisma and the Origins of the Research University, Chicago-London 2006.

Cognitive Models of Science, R.N. Giere, H. Feigl (eds.), Minneapolis 1992.

Europäische Sozietätsbewegung und demokratische Tradition. Die europäischen Akademien der Frühen Neuzeit zwischen Frührenaissance und Spätaufklärung, t. 1-2, K. Garber, H. Wismann, W. Siebers (hrsg.), Tübingen 1996. 
Giere R.N., Explaining Science: A Cognitive Approach, Chicago 1988.

Head R.C., Making Archives in Early Modern Europe: Proof, Information, and Political Record-Keeping, 1400-1700, Cambridge 2019.

Henry J., The Scientific Revolution and the Origins of Modern Science, Basingstoke 2002.

The Institutionalization of Science in Early Modern Europe, M. Feingold, G. Giannini (eds.), Leiden-Boston 2020.

The Italian Academies, 1525-1700: Networks of Culture, Innovation and Dissent, J.E. Everson, D.V.Reidy, L. Sampson (eds.), Cambridge-New York 2016.

Mooney C., The Republican War on Science, New York 2005.

Oreskes N., Conway E.M., Merchants of Doubt: How a Handful of Scientists Obscured the Truth on Issues from Tobacco Smoke to Global Warming, London 2010.

Robertson J., The Case for the Enlightenment: Scotland and Naples 1680-1760, Cambridge 2005.

Sady W., Ludwik Fleck, [w:] Stanford Encyclopedia of Philosophy, https://plato.stanford.edu/entries/fleck, 2012/2016.

Sady W., Struktura rewolucji relatywistycznej i kwantowej w fizyce, Kraków 2020.

Testa S., Le Accademie senesi e il network intellettuale della prima età moderna in Italia (1525-1700). Un progetto online, „Bullettino senese di Storia Patria” 117 (2010), s. 613-637. 
Studia Philosophica Wratislaviensia vol. XVI, fasc. 3, 2021 (C) for this edition by CNS 